\title{
NEUROLOGICAL SEQUELAE OF REDUCTION OF FRACTURE DISLOCATIONS OF THE CERVICAL SPINE
}

\author{
By R. D. Shrosbree, M.B., Ch.B. \\ Spinal Injuries Unit, Conradie Hospital, Cape Town, South Africa
}

\begin{abstract}
A retrospective study of 302 cases of cervical spine facet interlocking with neurological signs is presented. These are reviewed as regards aetiology and neurological recovery. There appears to be a neurological advantage in reduction of facet interlocking in this series.
\end{abstract}

Key words: Cervical spine; Facet interlocking; Tetraplegia.

\section{Introduction}

Cervical spinal cord injured patients with incomplete neurological lesions being treated on skeletal skull traction in an attempt to reduce facet interlocking were occasionally observed to show dramatic neurological improvement. This occurred at the commencement of treatment merely with the increasing of weights even before reduction of the vertebral lesion was achieved.

As a result it was decided to undertake a retrospective study in an attempt to assess the neurological sequelae of reduction and non-reduction of cervical spine facet interlocking.

\section{Material}

In the period November 1963 to November 1975, 1602 new cases of spinal cord injury were admitted to the Spinal Cord Injury Centre at Conradie Hospital (Table I). Of these 635 cases (40 per cent) sustained cervical spine lesions with cord involvement-302 cases ( 48 per cent) having interlocking of facets. Of these latter, II 8 cases (39 per cent) sustained unilateral and I83 cases (6I per cent) bilateral facet interlocking.

Since only cases surviving I2 weeks were assessed, 86 cases ( 28.5 per cent) with facet interlocking who died in the first 3 months were excluded from this series. The death rate amongst patients suffering from bilateral facet interlocking was significantly higher $(34 \%$ per cent) than the death rate amongst patients suffering from unilateral facet interlocking (19.5 per cent). The average length of stay in hospital was 9.8 months with a range from 3 months to 4 years.

\section{TABLE I}

Total admissions, Nov. 1963 to Nov. 1975

1602

Cervical vertebral injuries

Facet interlockings

Unilateral

Bilateral

Figures in brackets denotes deaths. 


\section{Aetiology}

The aetiological factors responsible for cervical spine facet interlocking followed the general trend of all injuries to the spinal column in the Conradie Spinal Unit (Table II).

In both groups, by far the most common single factor responsible, was motor vehicle accidents (involving driver, passenger or pedestrians) followed by falls, objects falling onto the patient's head or tripping while carrying objects on the head and assaults. The assaults were due to blows to the head and neck or inverting the victim and bouncing him on his head. This latter punishment is usually meted out to wives by their drunk husbands. Sports injuries dominated by rugby, formed a smaller section.

\section{Orthopaedic Lesion and Treatment}

The orthopaedic lesions in both groups involved the lower cervical spine mainly, from below the fourth cervical vertebra (Table III). The unilateral facet interlockings occurred maximally at $\mathrm{C}_{4} / 5$ and $\mathrm{C} 5 / 6$ (Fig. I) whereas the bilateral facet interlockings occurred mainly at $\mathrm{C} 5 / 6$ and $\mathrm{C} 6 / 7$ (Fig. 2).

TABLE II

Causes of injury

\begin{tabular}{lcc}
\hline $\begin{array}{c}\text { Causes of } \\
\text { injury }\end{array}$ & $\begin{array}{c}\text { Unilateral } \\
\text { locked } \\
\text { facets }\end{array}$ & $\begin{array}{c}\text { Bilateral } \\
\text { locked } \\
\text { facets }\end{array}$ \\
\cline { 3 - 3 } M.V.A. & 53 & 68 \\
Falls & 2 I & 2 I \\
Assaults & 7 & 8 \\
Objects & 7 & II \\
Rugby & 2 & 6 \\
Diving & 2 & 3 \\
Sports & 2 & 3 \\
Others & I & I \\
\hline
\end{tabular}

TABLE III

Orthopaedic lesions

\begin{tabular}{ccc}
\hline $\begin{array}{c}\text { Orthopaedic } \\
\text { lesions }\end{array}$ & $\begin{array}{c}\text { Unilateral } \\
\text { locked } \\
\text { facets }\end{array}$ & $\begin{array}{c}\text { Bilateral } \\
\text { locked } \\
\text { facets }\end{array}$ \\
\hline $\mathrm{C} 2 / 2$ & - & 2 \\
$\mathrm{C} 3 / 4$ & 3 & - \\
$\mathrm{C} 4 / 5$ & 34 & $2 \mathrm{I}$ \\
$\mathrm{C} 5 / 6$ & $3 \mathrm{I}$ & 49 \\
$\mathrm{C} 6 / 7$ & 24 & 37 \\
$\mathrm{C} 7$ & 3 & 12 \\
\hline
\end{tabular}



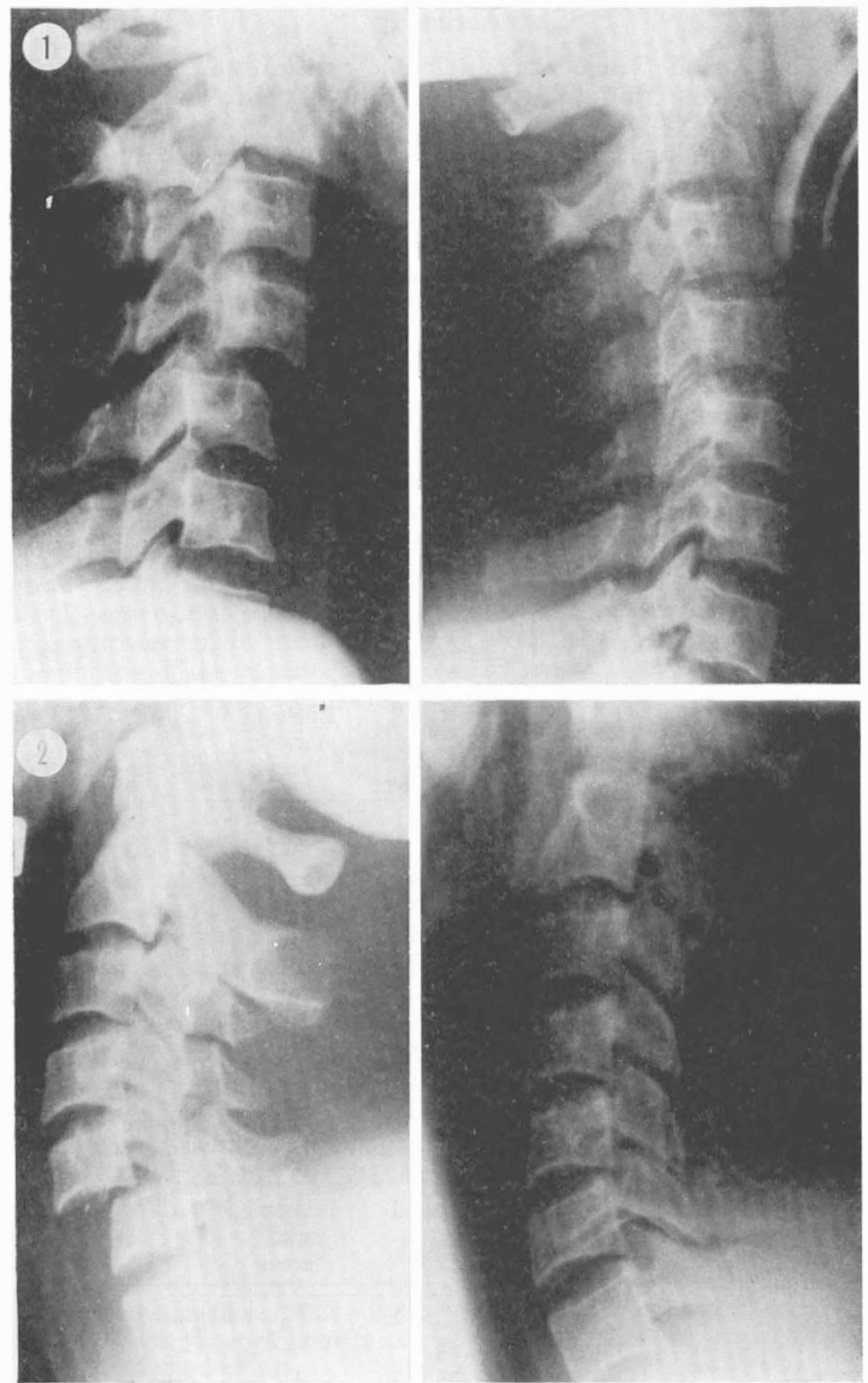

FIG. I

Shows dislocation $\mathrm{C}_{4} / 5$ with unilateral facet interlocking on the left followed by reduction on the right.

FIG. 2

Left side shows bilateral facet interlocking of facets $\mathrm{C}_{5} / 6$. Right side shows reduction of the dislocation. 
TABLE IV

\begin{tabular}{lll}
\hline Unilateral facet interlocking & 95 cases & \\
Reduced & 70 & $74 \%$ \\
Unreduced & 25 & $26 \%$ \\
Bilateral facet interlocking & I2 I cases & \\
Reduced & 77 & $64 \%$ \\
Partially reduced & 18 & $15 \%$ \\
Unreduced & 26 & $21 \%$ \\
\hline
\end{tabular}

The method of treatment applied was as stated by Key in 1975 for unilateral locked facets. However, due to the fact that bilateral facet interlocking is more easily recognised, most of these cases were treated on halter or skeletal traction, the latter by means of Crutchfield tongs. Halter traction is now only temporarily used when skeletal traction cannot be applied. Manipulation under anaesthesia was undertaken if these procedures were unsuccessful. Only three cases had open reductions.

Of the 95 patients with unilateral facet interlocking 70 ( 74 per cent) were reduced and 25 (26 per cent) remained unreduced (Table IV). Seventy-seven (64 per cent) of the I I I cases of bilateral facet interlocking were reduced completely (Fig. 2), I8 were partially reduced from bilateral to unilateral facet interlocking (Fig. 3), while 26 (2I per cent) remained unreduced (Fig. 4).

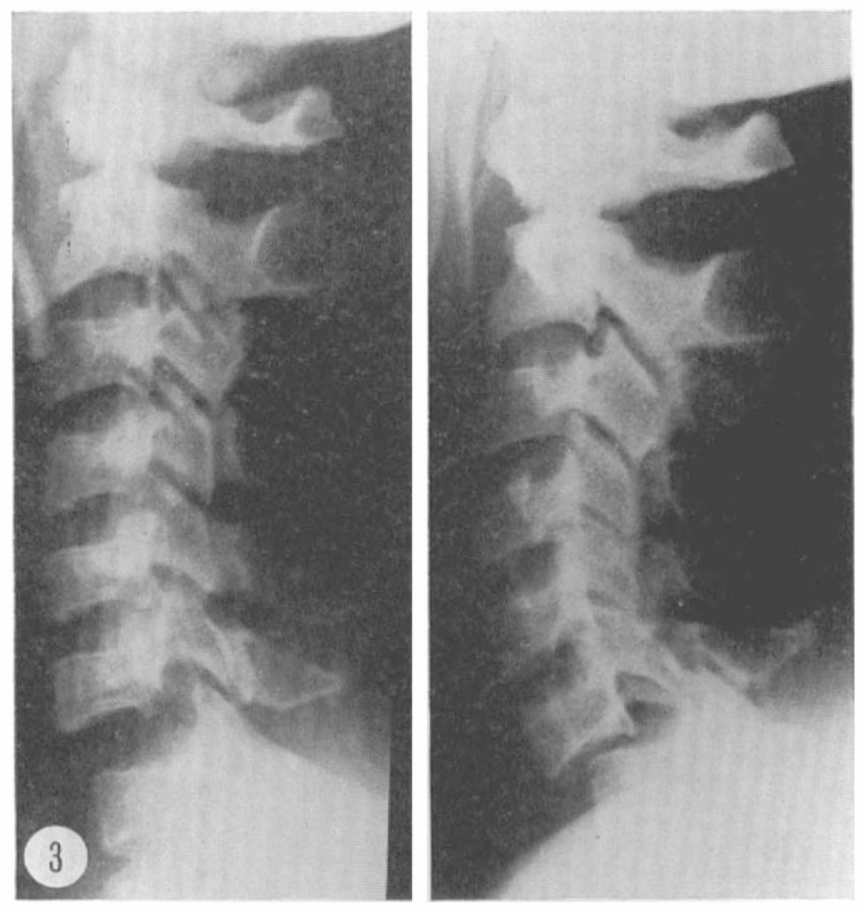

FIG. 3

Radiograph on the left shows dislocation with bilateral facet interlocking C6/7 and on the right partial reduction to unilateral locked facet. 


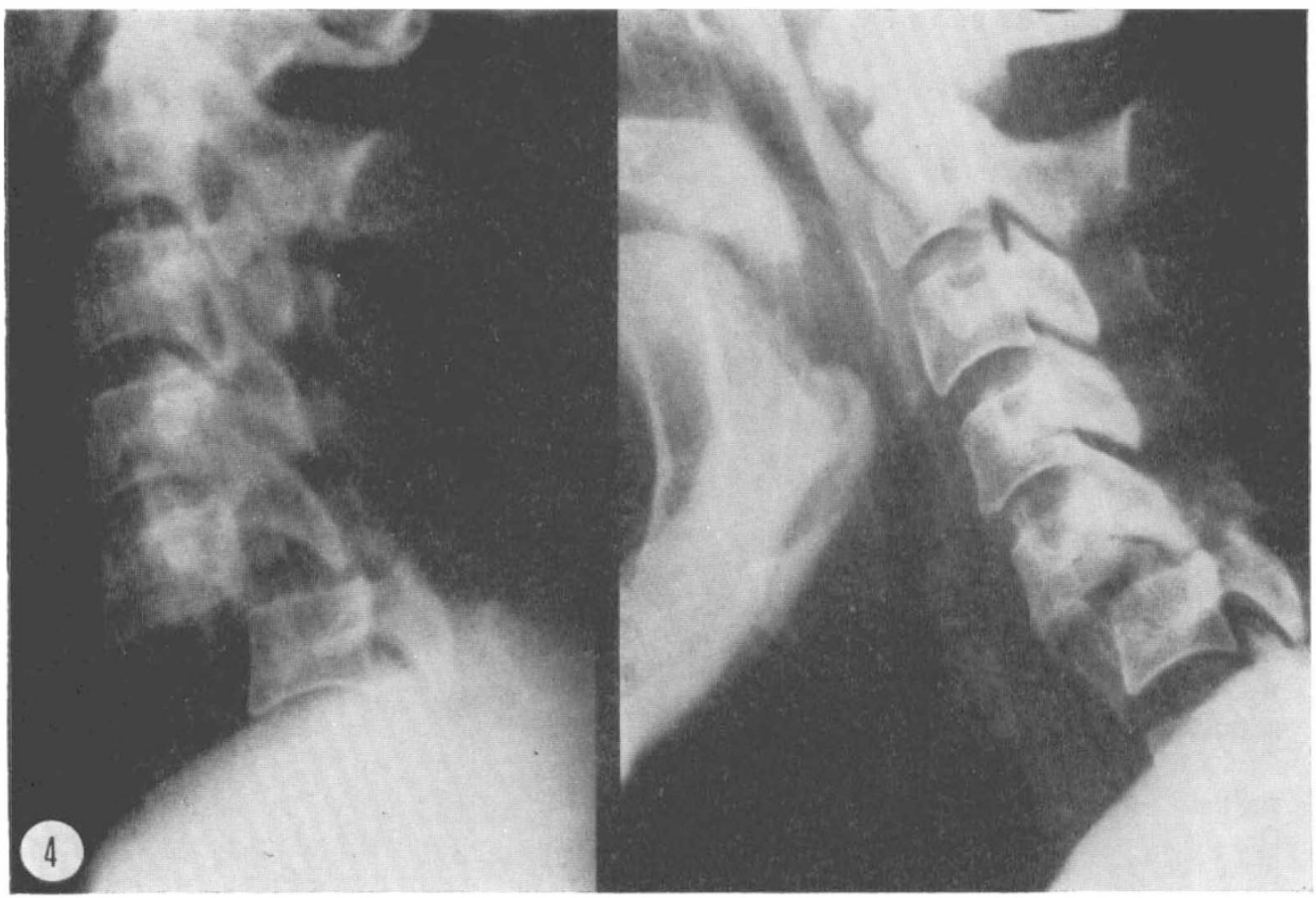

FIG. 4

Radiograph on the left shows dislocation $\mathrm{C}_{5} / 6$ with bilateral facet interlocking and on the right non-reduction.
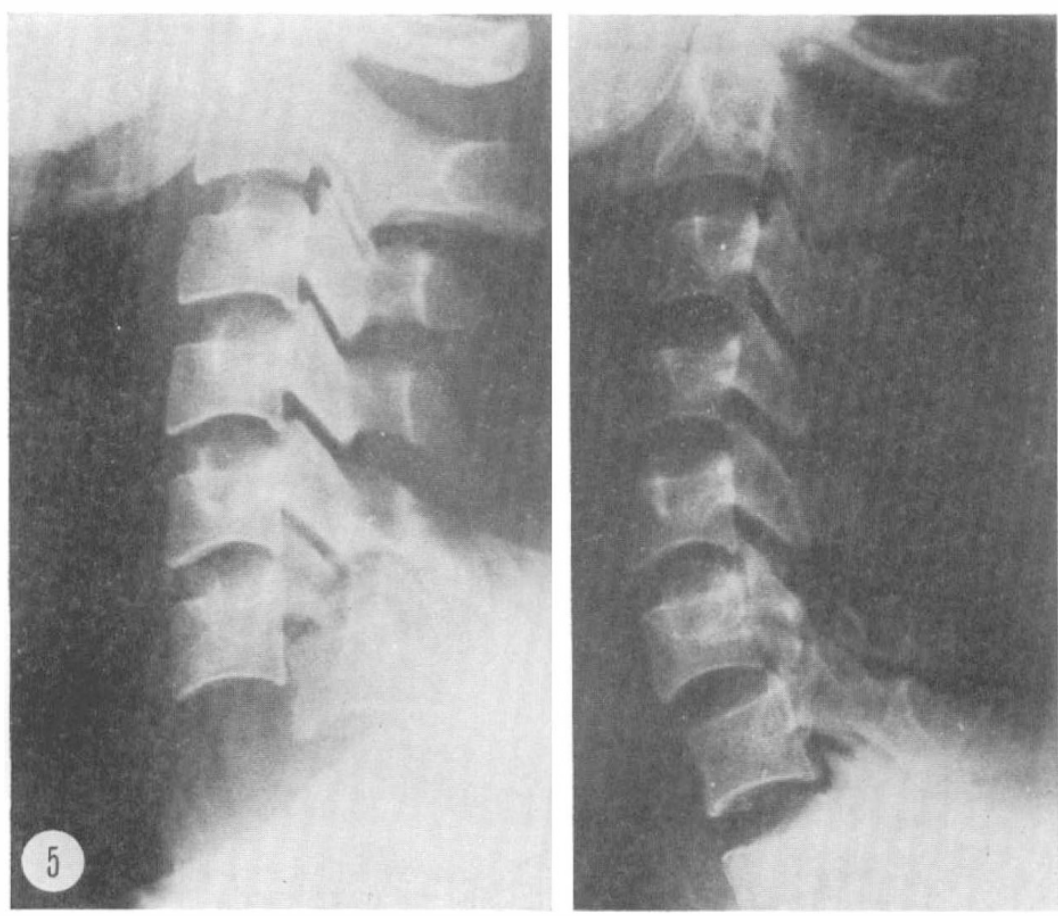

FIG. 5

Left side shows complete dislocation C6/7. Right side shows reduction of the dislocation. 


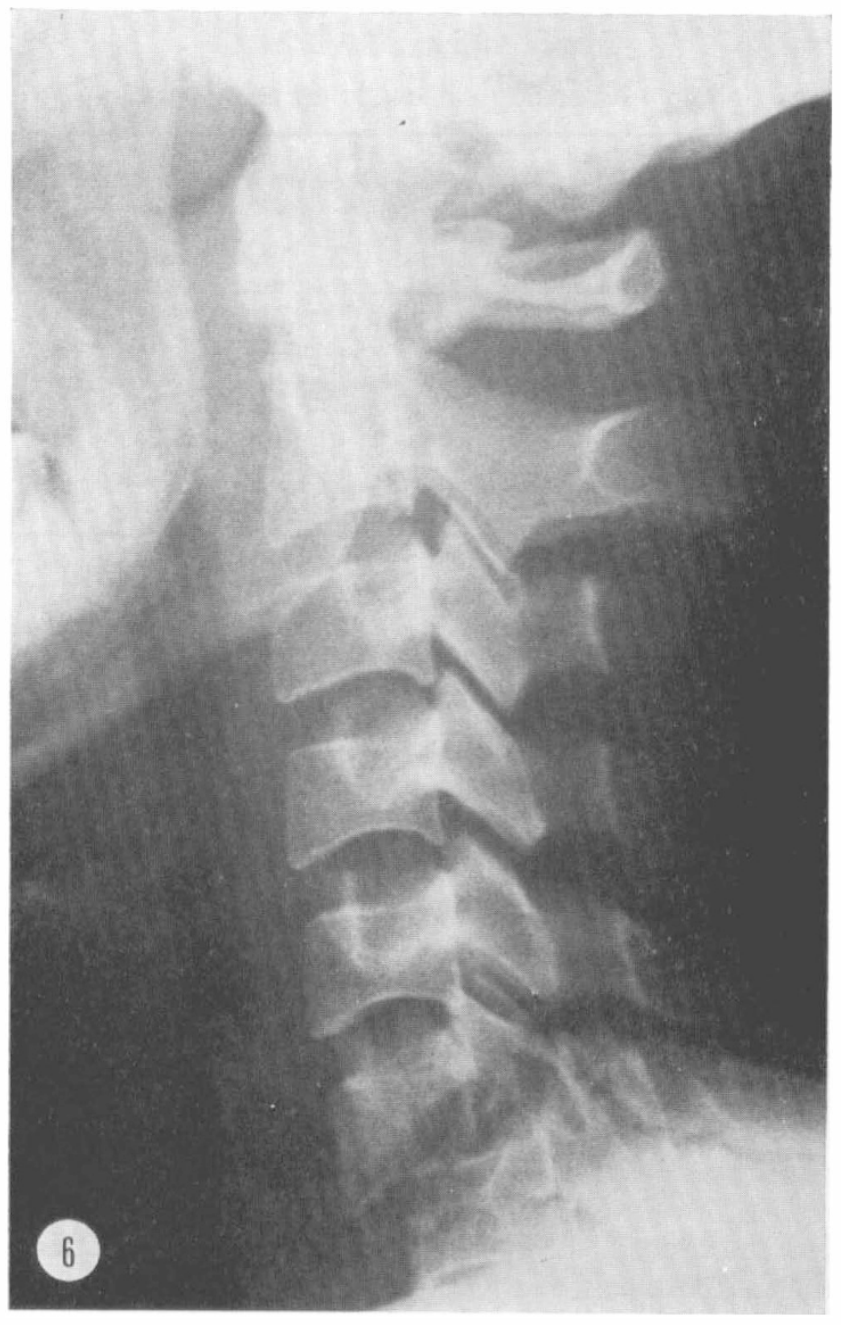

FIG. 6

Shows redislocation of the reduction of Fig. 5 .

\section{Neurology}

To avoid confusion the neurological level indicated is the last completely normal level. Several complete lesions had slight sparing for one or two levels below that stated. Obviously many of these recovered one or two levels in the course of time but were included in the complete group.

The majority of patients had neurological levels in the middle and lower cervical spinal cord (Table V). Thirty-two patients (35 per cent) with unilateral locked facets were complete lesions whereas 84 (6o per cent) of the patients with bilateral locked facets had complete lesions.

The system of classification devised by Frankel et al. (1969) is used to indicate the neurological status on admission and discharge in order to compare in each group the neurological improvement between the reduced and unreduced cases 


\section{TABLE V}

Neurological levels on admission

\begin{tabular}{lcccc}
\hline & \multicolumn{2}{c}{$\begin{array}{c}\text { Unilateral locked } \\
\text { facets }\end{array}$} & \multicolumn{2}{c}{$\begin{array}{c}\text { Bilateral locked } \\
\text { facets }\end{array}$} \\
\cline { 2 - 5 } & Complete & Incomplete & Complete & Incomplete \\
\hline C4 & I5 & 2I & 4 I & I6 \\
C5 & II & 2I & 24 & 9 \\
C6 & 3 & I2 & I2 & 3 \\
C7 & 3 & 7 & 6 & 4 \\
C8 & - & I & I & I \\
No loss & I & & & \\
\hline
\end{tabular}

\section{TABLE VI}

Neurological classification

\begin{tabular}{ll}
\hline Grade A & complete neurological lesions \\
Grade B & sensory sparing only \\
Grade C & motor useless \\
Grade D & motor useful \\
Grade E & recovery normal \\
\hline
\end{tabular}

(Table VI). In this classification improvement from one grade to another is significant. Tables VII to X show the improvement or lack of improvement in the various groups. The first letter denotes neurology on admission and the second, neurology on discharge. Re-dislocations were grouped with the unreduced cases.

Twenty-nine cases (4I per cent) with unilateral facet interlocking which were reduced showed improvement (Table VIII) against eight cases ( 32 per cent) which remained unreduced. All cases of unilateral locked facets which were complete on admission remained so.

Eighty-four cases with bilateral facet interlocking were complete neurological lesions on admission. Sixty-one (73 per cent) were reduced or partially reduced and of these ten cases ( 16 per cent) showed significant neurological recovery (Table IX). None of the remaining 23 cases which remained unreduced (including eight cases which redislocated) showed any significant recovery.

Thirty-seven bilateral facet interlockings with incomplete neurological lesions were initially reduced or partially reduced. (Three of these redislocated and are included in the unreduced group). Twenty-six (including two of the three which redislocated) showed neurological improvement.

\section{Discussion}

Motor vehicle accidents were by far the commonest cause of facet interlocking of the cervical spine in this series.

The most common site of interlocking is between $\mathrm{C}_{4}-5$ and $\mathrm{C}_{5}-6$ in unilateral and between $\mathrm{C}_{5-6}$ and C6-7 in bilateral facet interlocking. Thus the lesions involved the lower cervical spine mainly. 
Unilateral facet interlocking

TABLE VII

TEEDUCED

\begin{tabular}{|r|r|r|r|r|}
\hline $\mathrm{AA}$ & $\mathrm{AB}$ & $\mathrm{AC}$ & $\mathrm{AD}$ & $\mathrm{AE}$ \\
22 & 0 & 0 & 0 & 0 \\
\hline $\mathrm{BA}$ & $\mathrm{BB}$ & $\mathrm{BC}$ & $\mathrm{BD}$ & $\mathrm{BE}$ \\
0 & 7 & 2 & 13 & 2 \\
\hline $\mathrm{CA}$ & $\mathrm{CB}$ & $\mathrm{CC}$ & $\mathrm{CD}$ & $\mathrm{CE}$ \\
0 & 0 & 0 & 4 & 1 \\
\hline $\mathrm{DA}$ & $\mathrm{DB}$ & $\mathrm{DC}$ & $\mathrm{DD}$ & $\mathrm{DE}$ \\
0 & 0 & 0 & 12 & 7 \\
\hline $\mathrm{EA}$ & $\mathrm{EB}$ & $\mathrm{EC}$ & $\mathrm{ED}$ & $\mathrm{EE}$ \\
0 & 0 & 0 & 0 & 0 \\
\hline
\end{tabular}

Figures in brackets denote

\begin{tabular}{|r|r|r|r|r|}
\hline $\mathrm{AA}$ & $\mathrm{AB}$ & $\mathrm{AC}$ & $\mathrm{AD}$ & $\mathrm{AE}$ \\
9 & 0 & & 0 & 0 \\
\hline $\mathrm{BA}$ & $\mathrm{BB}$ & $\mathrm{BC}$ & $\mathrm{BD}$ & $\mathrm{BE}$ \\
0 & $3(1)$ & 2 & $\mathrm{O}(I)$ & 0 \\
\hline $\mathrm{CA}$ & $\mathrm{CB}$ & $\mathrm{CC}$ & $\mathrm{CD}$ & $\mathrm{CE}$ \\
0 & 0 & 0 & 3 & 1 \\
\hline $\mathrm{DA}$ & $\mathrm{DB}$ & $\mathrm{DC}$ & $\mathrm{DD}$ & $\mathrm{DE}$ \\
0 & 0 & 0 & 4 & 1 \\
\hline $\mathrm{EA}$ & $\mathrm{EB}$ & $\mathrm{EC}$ & $\mathrm{ED}$ & $\mathrm{EE}$ \\
0 & 0 & 0 & 0 & $0(1)$ \\
\hline
\end{tabular}
redislocated

TABLE VIII

UUNREDUCED

Bilateral facet interlocking

TABLE IX

REDUCED

\begin{tabular}{|c|c|c|c|l|}
\hline $\mathrm{AA}$ & $\mathrm{AB}$ & $\mathrm{AC}$ & $\mathrm{AD}$ & $\mathrm{AE}$ \\
$46(5)$ & $3(1)$ & $2(1)$ & $1(2)$ & 0 \\
\hline $\mathrm{BA}$ & $\mathrm{BB}$ & $\mathrm{BC}$ & $\mathrm{BD}$ & $\mathrm{BE}$ \\
0 & $5(1)$ & 1 & $7(4)$ & 1 \\
\hline $\mathrm{CA}$ & $\mathrm{CB}$ & $\mathrm{CC}$ & $\mathrm{CD}$ & $\mathrm{CE}$ \\
0 & 0 & 0 & $4(1)$ & 0 \\
\hline $\mathrm{DA}$ & $\mathrm{DB}$ & $\mathrm{DC}$ & $\mathrm{DD}$ & $\mathrm{DE}$ \\
0 & 0 & 0 & $2(1)$ & $4(2)$ \\
\hline $\mathrm{EA}$ & $\mathrm{EB}$ & $\mathrm{EC}$ & $\mathrm{ED}$ & $\mathrm{EE}$ \\
0 & 0 & 0 & 0 & 1 \\
\hline
\end{tabular}

Figures in brackets denote partially reduced
TABLE X

UNREDUCED

\begin{tabular}{|c|c|c|c|l|}
\hline $\mathrm{AA}$ & $\mathrm{AB}$ & $\mathrm{AC}$ & $\mathrm{AD}$ & $\mathrm{AE}$ \\
$\mathrm{I}(8)$ & 0 & 0 & 0 & 0 \\
\hline $\mathrm{BA}$ & $\mathrm{BB}$ & $\mathrm{BC}$ & $\mathrm{BD}$ & $\mathrm{BE}$ \\
0 & $\mathrm{O}(1)$ & $\mathrm{O}(1)$ & 0 & 0 \\
\hline $\mathrm{CA}$ & $\mathrm{CB}$ & $\mathrm{CC}$ & $\mathrm{CD}$ & $\mathrm{CE}$ \\
0 & 0 & 0 & $\mathrm{O}(1)$ & 0 \\
\hline $\mathrm{DA}$ & $\mathrm{DB}$ & $\mathrm{DC}$ & $\mathrm{DD}$ & $\mathrm{DE}$ \\
0 & 0 & 0 & 0 & 0 \\
\hline $\mathrm{EA}$ & $\mathrm{EB}$ & $\mathrm{EC}$ & $\mathrm{ED}$ & $\mathrm{EE}$ \\
0 & 0 & 0 & 0 & 0 \\
\hline
\end{tabular}

Figures in brackets denote redislocated

There is usually less than 50 per cent vertebral body shift with unilateral facet interlocking (Fig. I) and more than 50 per cent with bilateral facet interlocking (Fig. 2). The antero-posterior (A-P) diameter of the spinal canal is diminished to the same extent. This fact is probably the reason for the 66 per cent incomplete neurological lesions with unilateral facet interlocking in this series, whereas only 3I per cent were incomplete neurological lesions with bilateral facet interlocking.

Although the spinal canal is only decreased by less than half of its A-P diameter in unilateral facet interlocking, there seems to be a neurological advantage 
in achieving reduction-4I per cent of cases showed neurological improvement after reduction and $3 \mathrm{I}$ per cent without reduction, i.e. a Io per cent advantage with reduction.

Amongst the cases with bilateral facet interlocking, 28 per cent improved neurologically after reduction or partial reduction whereas only 7 per cent of the unreduced cases improved. These latter cases had actually been reduced, but redislocated, possibly indicating that initial reduction may have enhanced the chances of neurological recovery.

Sixteen per cent of cases with bilateral facet interlocking who, on admission, had complete neurological lesions and were successfully reduced showed significant neurological recovery. This may be due to the fact that the initial neurological examination was undertaken at the stage of maximal neurological loss resulting from oedema of the cord and spinal shock (Michaelis, 1969). With the restoration of the A-P diameter of the spinal canal and the regression of the above factors over the next few weeks further cord damage was prevented. This does not apply to the unreduced cases and could therefore be the reason for the neurological lesion remaining complete.

\section{Conclusion}

I. In this series, motor vehicle accidents were the commonest cause of facet interlocking of the cervical spine.

2. The commonest sites of unilateral facet interlocking are $\mathrm{C}_{4} / 5$ and $\mathrm{C}_{5} / 6$.

3. The most common sites of bilateral facet interlocking are $\mathrm{C}_{5} / 6$ and $\mathrm{C6} / 7$.

4. Two thirds of unilateral facet interlocking were incomplete neurological lesions.

5. More than two-thirds of the bilateral facet interlockings were initially complete neurological lesions.

6. There appears to be a neurological advantage in the reduction of unilateral facet interlockings.

7. Reduction of bilateral facet interlocking appeared to show a definite advantage in achieving some degree of neurological recovery.

8. No cases showed any neurological deterioration after treatment.

Acknowledgements. I wish to thank Dr D. F. Smith, Medical Superintendent for permission to publish and Dr A. G. Key for her advice in the preparation of this paper.

\section{RÉSUMÉ}

Une étude des 302 cas d'injures a la colonne cervicale et ces facettes enclenchées avec des indication neurologiques est introduit. Ces 302 cas sont étudié au point de vue aetiologie et un guérison neurologique. Il semble qu'il y a un advantage neurologique dans la reduction des facettes enclenchées de ces cas.

\section{ZUSAMMENFASSUNG}

Das Resultat von 302 Fällen mit ineinander gresfenden Halswirbelsäulen Fassetten und mit neurologischen Symptomen wird beschrieben. Diese Fälle sind untersucht worden im Bezug auf Aetiologie, und neurologische Wiederherstellung. Die Reduktion der ineinaudergresfenden Fassetten scheint neurologisch vorteilhaft zu sein.

\section{REFERENCES}

Frankel, H. L., Hancock, D. O., Hyslop, G., Melzak, J., Michaelis, L. S., Ungar, G. H., VERNON, J. D. S. \& WALSH, J. J. (I969). The value of postural reduction in the initial management of closed injuries of the spine with paraplegia and tetraplegia, Part $\mathrm{I}$. Paraplegia, 7, 179. 
Guttmann, L. (1973). Spinal-Injuries. Comprehensive Management and Research. Blackwell Scientific Publications, Oxford.

KEY, A. G. (I975). Cervical spine dislocations with unilateral facet interlocking. Paraplegia, 14, 25I-258.

MichAeLis, L. S. (1969). International inquiry on neurological terminology and prognosis in paraplegia and tetraplegia. Paraplegia, 7, I-5.

RAND, R. W. \& CRANDALl, P. H. (1962). Central spinal cord syndrome in hyperextension injuries of the cervical spine. F. Bone foint Surg., 44A, I4I 5-I422.

SHROSBREE, R. D. (I977). Acute central cervical spinal cord syndrome-aetiology, age incidence and relationship to the orthopaedic injury. Paraplegia, 14, 25I-258. 